jects? And are the decisions as to what is 'good' for the local populace made locally, or in London? (One perceptive comment on the environmental impact assessment made for the Volta project was that it was made by Westerners for Westerners; what was needed was a team of 'barefoot anthropologists' to live among the people affected by the Volta dam, and then to recommend how they should be handled.) If the people who say "it couldn't happen here" will pause a moment, they may recall the preposterous tragedy of taking people out of down-at-heel terrace houses and hoisting them up into high rise flats; or resettling people from the cohesive and compassionate society of a slum into neat, clean, aseptic villas in a suburb.

Upheavals in our traditional ways of life are inevitable; we are in for a lot more of them; people will have to migrate from the closed steelmills of Corby as surely as they had to migrate from the waters of the Volta River. The British people are flexible and courageous enough to tolerate these upheavals. What they will not - and should not - tolerate is the pained surprise of planners when some of the remedies proposed from Whitehall are rejected. The way to minimize mistakes - they can't be avoided altogether - is to improve the standard of environmental impact assessment; and the way to do that is to study very carefully case-histories of past assessments, to diagnose where they went wrong and what they left out. David Hart's little book, despite its high price, ought to be on the bookshelves of planners; for he does what he sets out to do: he gives a case-study of politics and technology relevant not only to Ghana but to Britain.

Lord Ashby is Chancellor of Queen's University, Belfast, and a Fellow of Clare College, Cambridge.

\title{
Questions of energy
}

\section{Joseph S. Nye}

World Energy Issues and Policies. Edited by Robert Mabro. Pp.367. (Oxford University Press: 1980.) $£ 15, \$ 44.50$.

THIS volume is a collection of papers from the first Oxford Energy Conference, held at St Catherine's College in September 1979, and cosponsored by the Organization of Petroleum Exporting Countries and the Organization of Arab Petroleum Exporting Countries. The Secretaries-General of the two organizations provide two of the 28 papers in the book. Distinguished OPEC contributors also include Kuwait's Minister of Oil and Venezuela's Minister of Energy and Mines. Other essays are contributed by government, industry and academic figures from various oil-consuming and -producing nations. A brief introduction and summary is provided by the editor, Robert Mabro.

As might be expected in a diverse collection of conference papers, there is great uneveness of quality and style. Mabro explains that the essays have "not been heavily edited"' in order to avoid lag in publication and to preserve their flavour of authoritative statements. Fair enough, though the disparities on occasion jar somewhat - a brief section, "World Energy Outlook", pairs Wolf Hafele's 23 pages on world regional energy modelling over 50 years with three pages of casual observations by the late C.C. Pocock of Shell Oil.

A more important problem is the gaps in coverage. The resulting tone of the book certainly leans toward the energy establishment. The editor acknowledges some omissions and wishes he had an environmentally orientated paper to balance the chapter on nuclear energy written by an industry representative. He also regrets the absence of a contribution from a senior official of a major OECD country such as the United States, but explains that official speakers at the seminar were encouraged to speak off the record. A rule that may have been good for the conference, however, is not good for a book. The result is a meagre two chapters, one on the United States by an academic and one on the United Kingdom by a deputy undersecretary of energy, in the section on energy issues and policies of OECD countries. In contrast, there are six papers (including by highly placed OPEC officials) in the section on energy issues and policies of oilexporting countries. Moreover, the paper on United States' policy entitled "A Critical Overview", hardly purports to be a balanced presentation.

Despite the problems of uneveness and gaps, there are several useful papers in the volume, especially in the opening section on energy supply. Particularly interesting is the paired treatment of natural gas by Nordine Ait-Laoussine of Algeria and James Jensen of the United States. On the other hand, one would have thought coal deserved more than five brief pages. There are descriptive discussions of the Soviet Union and China by Michael Kaser and John Foster, and many of the papers by officials are of interest not because of their analytical insights, but because of their author's positions. If treated as a smorgasbord, the book succeeds in one of the editor's purposes in that it does present some interesting conference fare for a wider audience to sample.

Mabro also has an explicit political objective: "to improve the chances of success of any future formal dialogue which Governments sooner or later will have to initiate'. In his summary, Mabro says that "the urgent need for dialogue was almost unanimously recognized", but there was little agreement on modalities or scope of the agenda.

The idea of a dialogue between OPEC and consumers is currently fashionable in the aftermath of the Brandt Commission Report. A consumer-producer dialogue might help nations shift their focus to the potential long-term joint benefits to be gained. Such a dialogue might seek intergovernmental agreements to stabilize the oil market; for example, OPEC and IEA countries might agree on production targets and consumption limits (at first separately, and then in joint bargaining) which would allow for modest real price rises over the next decade. A band of prices might be established for the duration of the agreement. OPEC countries would agree to maintain sufficient spare capacity to increase production if a shortfall of production from any subgroup of producers threatened to push prices outside the band. They would cut production (or agree to permit consumers to increase demand above the agreed limits) if prices threatened to fall through the bottom of the band. Additional inducements might be needed to assure adequate production levels. For example, consumers might offer indexing of assets and assurances of assistance and market access for the new OPEC industries. Special credit or aid provisions might be agreed for oil-importing developing countries; some such countries could be included in bargaining sessions.

But a number of hard questions must be answered. Could the agenda be focused on energy? If other developing countries participate, will the world replay sterile North-South debates, but with much higher stakes than in the United Nations? Can the "Pandora's Box Effect" be controlled if nations start down the path to serious international collective bargaining?

Is a reasonable bargain likely? At modest prices there are divergent interests between those OPEC surplus producers who lean toward conservation and the highabsorbers interested in maximizing revenues. Large price increases (which maximize revenues and allow painless production cutbacks) tend to reconcile that division. Would OPEC countries be able to agree to a bargain that meant higher production and lower prices than the market would otherwise determine?

Does OPEC have sufficient cohesion to make a bargain stick? Thus far, OPEC countries have been unwilling to limit their separate sovereign control over production decisions concerning the resource that is their major source of power. They compete for power within the oil arena and they reserve the right to use oil as a weapon in wider political games. Given the politics of oil, and the domestic instability of many 
OPEC governments, how credible is an OPEC promise to increase production if a shortfall has political ramifications? And if an unintended interruption occurs, how likely is it that OPEC will be able to restrain the high-absorber members from charging what the market will bear? If, as is probable, they cannot, consumers will have paid higher-than-market prices in normal times in return for broken promises.

Would the benefits exceed the costs? Basically, consumers would gain a formal framework for debating production (and price) decisions that are now entirely in OPEC hands. Bilateral diplomacy can have some of the same effect. How much is it worth paying for this framework?

These questions do not mean that conversations with producer states are not useful, or that restoration of an international oil regime is not a worthy long-term goal. Various bilateral and multilateral discussions are essential. But efforts to reconstruct a satisfactory regime are unlikely to be fruitful unless hard questions have been carefully thought through. The volume at hand provides raw material for such thinking, but poses few of those questions and gives disappointingly few of the answers.

Joseph S. Nye is Professor of Government and Public Policy at Harvard University.

\section{The state of Arab science}

\section{Ziauddin Sardar}

Science and Science Policy in the Arab World. By A. B. Zahlan. Pp.205. (Croom Helm: 1980.) £13.95.

THE past decade has seen scientific and technological activity in the Middle East really come alive. While much of this activity is little more than simple transfer of equipment, expertise and personnel, there are, nevertheless, a number of projects which aim to make a real contribution to science development in the area and provide it with an indigenous base; to this end a number of technological universities and specialized institutes have been established to meet some of the more demanding needs of manpower and research.

The scale of this transfer of technology and its associated problems are in many respects unique and unparalleled, and demand urgent and detailed scholarly attention. Thus one turns to Antoine Zahlan's book with the hope of seeing these developments charted, analysed and placed in an appropriate scientific, social and political context. Indeed, few would be better qualified for such a job.

With so much to relate and analyse, it is sad to report that Zahlan has missed an excellent opportunity. His book is not just weak in content and rather limp in its analysis; worse, it is a book apparently based almost entirely on publicity brochures and official handouts. Probably the best part is the introduction where Zahlan allows himself some critical consideration. However, from that point onwards, the book consists of straightforward description, potted history and dubious statistics.

The opening chapter presents a general view of the growth of scientific activity in the Arab World. Zahlan uses three basic sources for his information: UNESCO's List of Scientific Papers Published in the Middle East (1948-1955), the now defunct Arab Science Abstracts (1973-1975) and Who is Publishing in Science. I would not be able to say anything about Arab science on the basis of these sources. Further I do not believe, as Zahlan does, that "scientific productivity measured in terms of publications of academic institutions is highly correlated with their scientific standing as assessed by leading scientists; it is also related to other outputs such as inventions, patents and the technological performance of the economy'. These sorts of criteria for scientific productivity may be applicable to highly developed economies with sophisticated scientific infrastructures, but not to developing economies where scientists have more pressing concerns than

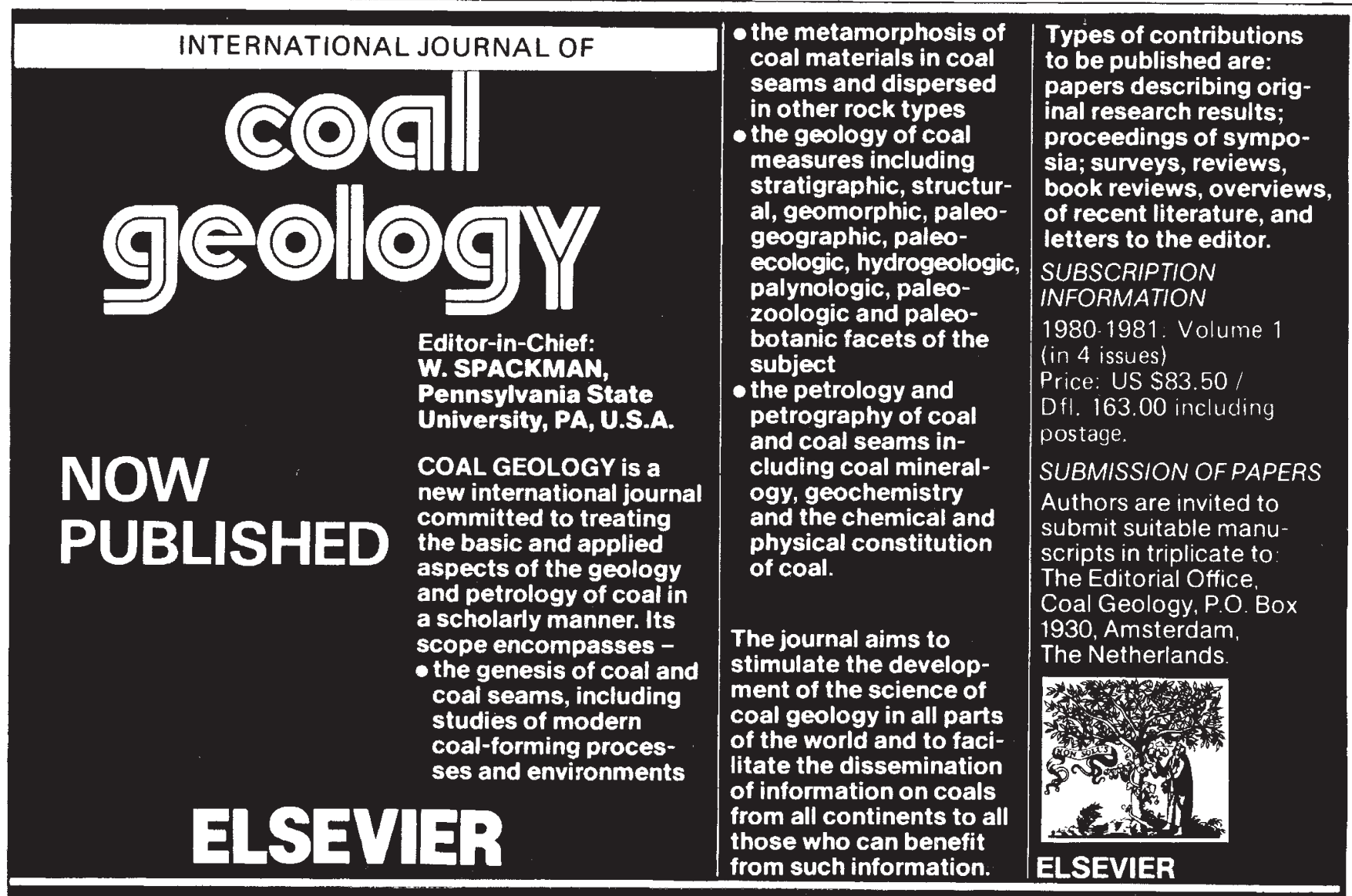

Send for your sample copy now. 